\title{
Farmer-Focused Tools to Improve Soil Health Monitoring on Smallholder Farms in the Morogoro Region of Tanzania
}

\begin{abstract}
Anna L. Testen, Department of Plant Pathology, The Ohio State University, OARDC, Wooster, 44691; Delphina P. Mamiro and Jackson Nahson, Department of Crop Science and Horticulture, Sokoine University of Agriculture, Morogoro, Tanzania; Nyambilila A. Amuri, Department of Soil and Geological Sciences, Sokoine University of Agriculture; Steven W. Culman, School of Environment and Natural Resources, The Ohio State University, OARDC, Wooster, 44691; and Sally A. Miller, ${ }^{\dagger}$ Department of Plant Pathology, The Ohio State University, OARDC, Wooster, OH 44691
\end{abstract}

Accepted for publication 17 January 2018.

\section{Abstract}

A participatory approach was used to improve smallholder tomato farmers' understanding of and access to soil health monitoring in the Morogoro Region of Tanzania. Baseline soil characteristics were gathered from 50 tomato fields in the region, local soil knowledge was elicited from farmers and used to develop a soil health card to qualitatively assess soil health, and farmers $(n=32)$ were trained on the use of a low-cost soil test kit to quantitatively assess soil health. Farmers most often described local indicators of soil health in terms of soil texture and tilth, soil color, soil water relations, and soil fertility. Following use of the soil test kit, farmers indicated increased awareness of soil testing services (Wilcoxon signed rank $Z=-3.0, P=0.001$ ), more agreed they had access to soil testing services $(Z=-2.7, P=0.004)$, and more agreed that soil management recommendations were easy to understand $(Z=-3.4, P<0.0001)$ compared with pre-exposure results. Farmers continued to use the soil health test kit and soil health card based on a follow-up survey administered 1 year after project completion. Participatory soil health monitoring projects can improve farmers' ability to monitor and manage soil health, potentially impacting sustained soil and plant health.

\section{Soil Health Monitoring Capacity in Developing Countries}

Poor soils limit crop productivity worldwide, yet this problem is especially pronounced in Africa (Vanlauwe and Giller 2006). Soil constraints significantly affect smallholder farmers who often lack the education, training, or resources to make the best management decisions for their soils. In the Morogoro Region of Tanzania, tomato is a major vegetable cash crop (Maerere et al. 2010), and low tomato yields are partially attributed to declining soil health (Ellis-Jones and Tengberg 2000; Minja et al. 2011). Yields of the staple crops maize and rice, often rotated with tomato, have also declined owing to deteriorating soil health (Paavola 2008). Morogoro farmers may produce two or more crops of tomatoes a year (Ponte 1998), which further strains soil health on farms in the region. Following the definition of Doran et al. (1996) that soil health is the "continued capacity of soil to function as a vital living system...to sustain biological productivity and promote plant and human health," we sought to develop a multifaceted project to identify key soil health constraints in this region and improve access to soil health testing for smallholder tomato farmers.

Several approaches can be used to improve smallholder access to soil testing, including improving national agricultural testing infrastructure (both public and private), increasing extension agents' capacity to test soils, or directly training farmers to perform their own soil evaluations. Novel strategies have been employed to

${ }^{\dagger}$ Corresponding author: Sally A. Miller; E-mail: miller.769@osu.edu

Funding: Funding was provided by United States Agency for International Development (concept ID 10.13039/100000200, United States Borlaug Fellows in Global Food Security and iAgri 621-A-00-11-00009-00).

(C) 2018 The American Phytopathological Society improve soil testing within countries, including the use of a mobile soil testing truck in Uganda (Esipisu 2015; Nakkazi 2014) and the SoilDoc, a portable soil test kit for extension agent use (American Society of Agronomy/Crop Science Society of America 2013). These strategies often take a top-down approach, usually engaging local extension agent networks, to improve soil health monitoring and management, but directly engaging farmers to improve these aspects of soil health requires a multifaceted, participatory approach. Direct approaches (Ditzler and Tugel 2002) for improving farmers' assessments of their soils include soil health cards (Romig et al. 1995) and low-cost soil health test kits (Liebig et al. 1996). Improved farmer knowledge of soil health indicators, even if assessed qualitatively, can lead to improved soil stewardship (Wander and Drinkwater 2000).

Programs designed to improve farmers' ability to monitor soil health must improve farmers' capacity to evaluate both local and technical indicators of soil health. Local indicators are usually farmerdefined, qualitative in nature, and can be assessed in the field. In contrast, technical indicators are defined by researchers, quantitative in nature, and usually must be assessed in laboratories (Barrios et al. 2000). Local soil knowledge can be formalized into tools that farmers can use to evaluate their own soils, and simple tests can be introduced for assessment of technical indicators (Barrios et al. 2000; Romig et al. 1995).

Local farmer knowledge of soils must be taken into account to improve soil health management by smallholder farmers. Ethnopedological studies (studies of local soil knowledge) have been conducted in East Africa in several cropping systems (Mairura et al. 2007; Maro et al. 2013; Mowo et al. 2006; Murage et al. 2000; Oudwater and Martin 2003). Ethnopedological studies can provide information on local soil taxonomies (Ettema 1994), local views on 
soil processes and soil quality (Niemeijer and Mazzucato 2003), local soil management practices (Ellis-Jones and Tengberg 2000), and how farmers identify soils suitable for planting (Barrera-Bassols and Zinck 2003). Local soil knowledge, such as identifying which soils are best for crops, can be supported by experimental data (Erkossa et al. 2004; Murage et al. 2000). Identifying local soil knowledge can help researchers identify constraints and address these constraints using appropriate technologies, such as locally available fertilizers and organic matter amendments or improved crop rotations.

The goals of this study were to (i) survey soil fertility characteristics in representative tomato fields, (ii) assess local soil knowledge, and (iii) improve smallholder tomato farmers' ability to monitor and manage soil health in the Morogoro Region. Farmers were provided with methods to evaluate both local and technical indicators of soil health through the introduction of a soil health card and low-cost soil health test kit.

\section{Establishing a Baseline Understanding of Regional Soil Health}

Baseline soil fertility characteristics in tomato production fields and local soil knowledge were assessed to develop an understanding of soil health in the Morogoro Region. Five villages representative of the Morogoro Region in tomato production practices were selected with the help of local agricultural officials: Msufini $\left(6^{\circ} 17^{\prime} 29.16^{\prime \prime} \mathrm{S}\right.$, $\left.37^{\circ} 28^{\prime} 19.92^{\prime \prime} \mathrm{E}\right)$, Mabana (6²8'17.94"S, 37²5'34.62"E), Msongozi ( $\left.7^{\circ} 4^{\prime} 10.20^{\prime \prime} \mathrm{S}, 37^{\circ} 20^{\prime} 39.12^{\prime \prime} \mathrm{E}\right)$, Mlali (657'39.60"S, 37 $\left.32^{\prime} 11.64^{\prime \prime} \mathrm{E}\right)$, and Kibagala $\left(7^{\circ} 6^{\prime} 12.78^{\prime \prime} \mathrm{S}, 37^{\circ} 35^{\prime} 9.96^{\prime \prime} \mathrm{E}\right)$. Participating farmers were selected by village leaders and were representative of tomato farmers in each village. Local soil knowledge and soil samples for baseline analysis of soil conditions were collected in all villages. Soil health test kit training and evaluations were conducted in Msufini, Mabana, and Msongozi because farmers in these villages were also participating in tomato variety selection trials (Testen et al. 2016a).

Soil samples from 10 tomato fields in each village were collected to a depth of $15 \mathrm{~cm}$ using a shovel (10 samples per field), composited, homogenized, air-dried and passed through a $2-\mathrm{mm}$ sieve in preparation for soil testing. Fields were selected randomly in conjunction with a tomato disease survey (Testen et al. in press) and were representative of different production conditions in each village. Analyses were conducted at the soil testing laboratory at Sokoine University of Agriculture (Morogoro, Tanzania). Soils were evaluated for $\mathrm{pH}$ (1:2.5 in water), electrical conductivity (EC) (1:2.5 in water), texture (Bouyoucos hydrometer method [Day 1965]), organic carbon (Walkley-Black method [Nelson and Sommers 1996]), total nitrogen (modified Kjeldahl method [Wilke 2005]), phosphorus (Bray 1 method [Bray and Kurtz 1945]), and exchangeable bases (potassium, calcium, magnesium, and sodium; ammonium acetate extraction followed by quantification in an atomic absorption spectrometer [Sumner and Miller 1996]). Active carbon was determined using previously described methods (Culman et al. 2012; Weil et al. 2003). Root rot and root knot nematode levels in these soils were assessed in a different study (Testen et al. in press); root knot nematode was a common biotic constraint as it was found in 44 of 50 fields. Differences in soil fertility parameters between villages were determined using a one-way ANOVA in Minitab (Minitab, State College, PA) with an $\alpha$ of 0.1 .

Mean soil $\mathrm{pH}$ and mean EC were within the acceptable range for tomato production in all villages (Table 1) (Heuvelink 2005).

\begin{tabular}{|c|c|c|c|c|c|}
\hline \multicolumn{6}{|c|}{$\begin{array}{l}\text { TABLE } 1 \\
\text { Characteristics of soils in fields used for tomato production in the Morogoro Region of Tanzania. The mean of } \\
\text { each characteristic is shown followed by the range in parentheses. }\end{array}$} \\
\hline Characteristic & Msufini & Msongozi & Mabana & Mlali & Kibagala \\
\hline $\mathrm{pH}^{\mathrm{t}}$ & $7.0 \mathrm{ab}(6.5-7.4)$ & $7.4 \mathrm{a}(7.0-8.1)$ & $7.0 \mathrm{ab}(6.5-7.4)$ & $6.9 \mathrm{~b}(6.2-7.5)$ & $6.0 \mathrm{c}(5.4-6.2)$ \\
\hline $\mathrm{EC}^{\mathrm{t}}(\mathrm{mS} / \mathrm{cm})$ & $0.14(0.08-0.25)$ & $0.12(0.07-0.19)$ & $0.13(0.09-0.25)$ & $0.12(0.07-0.17)$ & $0.13(0.1-0.2)$ \\
\hline Texture $^{\mathrm{u}}$ & $\begin{array}{l}\text { Sandy clay loam (3), } \\
\text { sandy loam (5), } \\
\text { sandy clay (2) }\end{array}$ & $\begin{array}{l}\text { Sandy loam (2), loamy } \\
\text { sand (1), sandy } \\
\text { clay (1), sandy clay } \\
\text { loam (6) }\end{array}$ & $\begin{array}{l}\text { Loamy sand (3), sandy } \\
\text { loam (2), sandy clay } \\
\text { loam (4), clay (1) }\end{array}$ & $\begin{array}{l}\text { Sandy loam (7), sandy } \\
\text { clay loam (3) }\end{array}$ & $\begin{array}{l}\text { Sandy loam (4), clay } \\
\text { loam (3), sandy clay } \\
\text { loam (3) }\end{array}$ \\
\hline Organic carbon $^{\mathrm{v}}(\mathrm{g} / \mathrm{kg})$ & 24.4 a $(11.8-35.0)$ & $18.0 \mathrm{ab}(8.8-34.6)$ & 13.4 b (6.9-20.2) & 12.9 b (8.9-15.2) & 20.3 a (11.4-26.4) \\
\hline Active carbon ${ }^{\mathrm{w}}$ (mg/kg) & 639 a (377-856) & $488 \mathrm{ab}(254-895)$ & $411 \mathrm{~b}(263-577)$ & 374 b (294-437) & 627 a $(419-791)$ \\
\hline Total nitrogen $\mathrm{x}(\mathrm{g} / \mathrm{kg})$ & $1.4 \mathrm{ab}(0.9-2.1)$ & $1.3 \mathrm{abc}(0.6-2.2)$ & $1.0 \mathrm{bc}(0.5-1.6)$ & 0.9 c $(0.6-1.2)$ & 1.8 a $(1.3-2.6)$ \\
\hline Phosphorus $^{\mathrm{y}}$ (mg/kg) & 50.6 a $(25.5-66.4)$ & $36.9 \mathrm{ab}(21.4-51.8)$ & 17.2 c $(7.8-36.5)$ & $31.0 \mathrm{bc}(3.7-50.8)$ & $34.4 \mathrm{~b}(10.4-48.1)$ \\
\hline $\begin{array}{l}\text { Exchangeable } \\
\text { magnesium }^{\mathrm{z}}(\mathrm{mg} / \mathrm{kg})\end{array}$ & 446 (221-649) & $570(204-1,025)$ & $475(77-1,063)$ & $522(280-1,177)$ & $418(229-751)$ \\
\hline $\begin{array}{l}\text { Exchangeable } \\
\text { sodium }^{\mathrm{z}}(\mathrm{mg} / \mathrm{kg})\end{array}$ & $25(9-51)$ & $25(16-51)$ & $28(12-67)$ & $30(9-106)$ & $30(21-39)$ \\
\hline
\end{tabular}

${ }^{\mathrm{s}}$ Soils were collected from 10 representative fields in each of five villages and tested at Sokoine University of Agriculture in Morogoro, Tanzania. Means in a row that differ significantly are indicated by a different letter based on Tukey's honest significant difference with family-wise error rate of $\alpha=0.1$.

${ }^{t} 1: 2.5$ in water. $\mathrm{EC}=$ electrical conductivity.

${ }^{u}$ Bouyoucos hydrometer method (Day 1965); number in parentheses indicates the number of fields.

${ }^{v}$ Walkley-Black method (Nelson and Sommers 1996).

${ }^{w}$ Permanganate oxidizable carbon (Culman et al. 2012; Weil et al. 2003).

${ }^{x}$ Modified Kjeldahl method (Wilke 2005).

${ }^{y}$ Bray-1 method (Bray and Kurtz 1945).

${ }^{\mathrm{z}}$ Ammonium acetate extraction followed by quantification in an atomic absorption spectrometer (Sumner and Miller 1996). 
Msongozi was the only village with soils outside the range of acceptable $\mathrm{pH}$, with two soils with $\mathrm{pH}$ above 8.0, and Kibagala soils had significantly lower $\mathrm{pH}$ than soils in the other four villages $(P<0.0001)$. Msufini and Kibagala soils had significantly higher levels of organic carbon $(P<0.0001)$ and active carbon $(P<0.0001)$ compared with those in Mabana and Mlali. Kibagala soils also had significantly higher levels of nitrogen than soils in Mabana and Mlali $(P<0.0001)$. Organic carbon and total nitrogen levels were similar to those of benchmark soils in the Morogoro Region (Msanya et al. 2003). Soils in Msufini, Msongozi, and Kibagala had significantly higher levels of phosphorus than those in Mabana $(P<0.0001)$. Msufini and Msongozi soils had significantly higher levels of potassium than those in Kibagala $(P=0.012)$. No villages differed significantly in their levels of exchangeable calcium, magnesium, and sodium in soils.

Local soil knowledge was gathered in individual and group activities. In the individual activity, farmers were given two prompts: to describe a soil that is good for tomato production and to describe a soil that is poor for tomato production. Farmers were also asked if they had a soil that was problematic for tomato production and, if so, to describe why that soil was problematic. Responses were gathered from 100 farmers (20 farmers per village). The group activity was conducted in groups of four to six farmers, randomly assigned by researchers, and 18 to 20 farmers participated in this activity in each village. Some of the farmers participating in the group activity also participated in the individual activity, and both activities were included because farmers could potentially have different responses when given individually or following group discussion. Farmer groups were asked to list 10 characteristics of soils that are good and 10 characteristics of soils that are poor for tomato production. Soil characteristics given in both activities were classified into groups of related soil health indicators (e.g., soil fertility, soil color, etc. [Barrios et al. 2000]). In the group activity, 20 groups of farmers provided 204 responses of indicators of good soils and 202 responses regarding indicators of poor soils for tomato production. In the individual activity, 100 farmers provided 195 responses for indicators of good soils and 166 responses for indicators of poor soils. Farmers gave responses that were classified into categories representing 11 groups of related soil health indicators including soil fertility, soil water relations, soilborne diseases, vegetation (weeds and other plants that grow naturally in fields), field location, soil color, soil texture and tilth, soil salt levels, soil temperature (whether soil stays cool or heats rapidly), soil versatility (soil holds multiple functions to farmers), and erosion.

Farmers described local indicators of soil health similarly in both the individual and group activities (Fig. 1, shown in percent of respondents for individual activity and percent of responses for group activity). Individual farmers most often described soils good for tomato production (Fig. 1A) in terms of texture and tilth, color, soil water interactions, and fertility, whereas soils poor for tomato production were described most often in relation to soil texture and tilth, water interactions, soil salt levels, soil color, and soil fertility. Good soils were often described as being black in color, a loam in texture, fertile, having good water-holding capacity yet well drained, and having vigorously growing weeds, such as Commelina benghalensis. Poor soils were often described as red in color, a clay or sand in texture, having poor fertility, salty, and having poor waterholding capacity and poorly growing (weak or chlorotic) weeds or an overabundance of weeds. Groups of farmers most often described good soils (Fig. 1B) in terms of soil texture and tilth, soil water interactions, and soil fertility. These three soil indicator categories were also most commonly used by groups to describe poor soils for tomato production. In group activities, farmers expanded on their
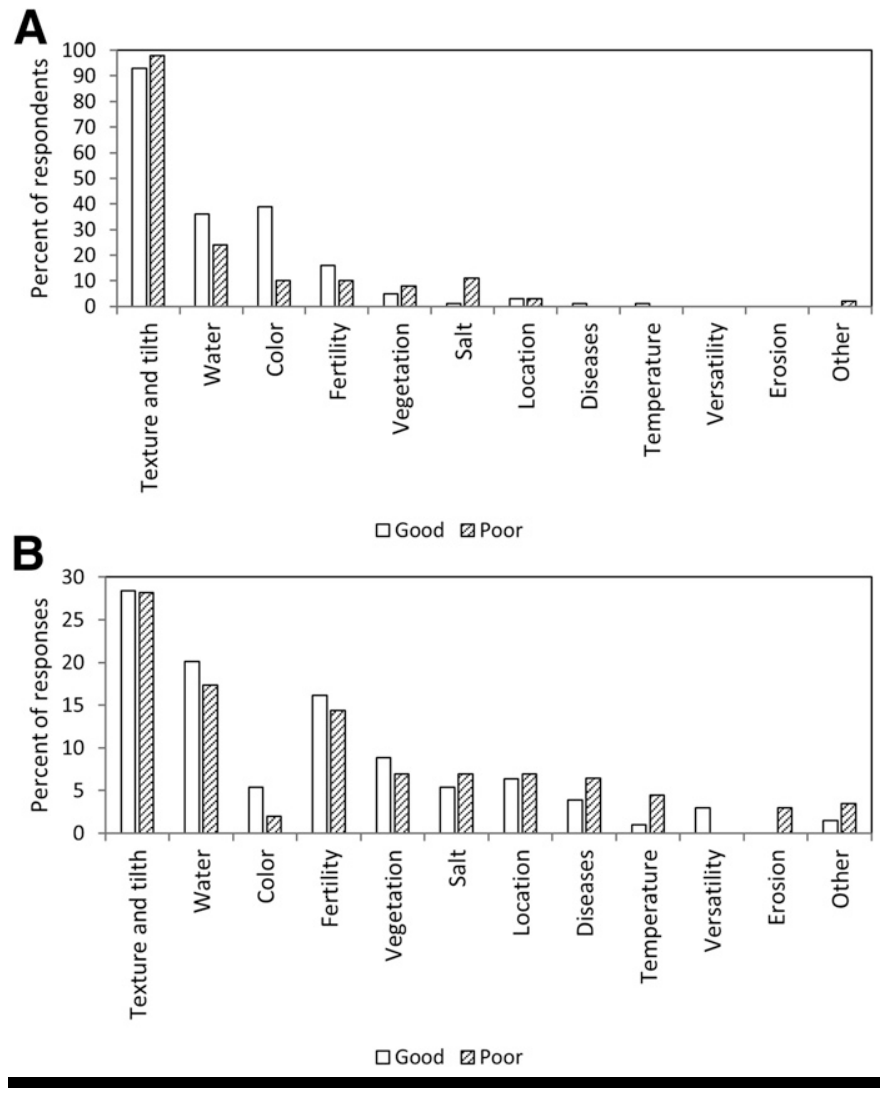

\section{FIGURE 1}

Local, farmer-described indicators of soils good and poor for tomato production. Individual farmers (20 per village in five villages) and groups of farmers (four to six farmers per group, four groups per village) provided their responses, which were then coded based on the soil health indicator they best represented. The percentage of respondents for the individual $(\mathbf{A})$ and percent of responses for the group activity (B) for each indicator grouping are shown for good and poor soils.

descriptions of soils, including more descriptions using more characteristics such as plant diseases, weed growth, and soil fertility, whereas color was used less often as a descriptor in these discussions.

Eighty-eight of 100 farmers self-identified soils that were problematic for tomato production in the individual activity. They attributed problems to soil fertility (30\% of responses), soil texture or tilth that was not conducive to tomato production (26\%), soil water issues $(15 \%)$, location of the field $(9 \%)$, soil salt levels $(5 \%)$, and several other constraints including excessive growth of weeds (4\%), soilborne diseases $(2 \%)$, soil temperature extremes $(3 \%)$, and erosion $(1 \%)$.

The most common farmer-described soil health indicators were incorporated into a soil health card (Romig et al. 1995; USDA NRCS Soil Quality Institute 1999). The soil health card (Tables 2 and 3 ) contained descriptions of 13 soil health indicators (soil life, compaction, infiltration, water holding capacity, crop vigor, soil salts, root health, tilth/workability, vegetation, aggregation, erosion, smell, and soil fertility). The soil health card was translated into Kiswahili by a native speaker with a Ph.D. in soil science and reflected the language used by farmers to describe soils. Qualitative descriptions of each indicator at poor, medium, or good levels of soil health were provided. Farmers could use these descriptions to assess each indicator in their fields. The reverse side of the card contained descriptions of soil management practices that improve or worsen the status of each 
indicator. Soil health cards were provided to participating farmers $(n=32)$ during the soil health test kit training and later to farmers in all surveyed villages $(n=100)$.

\section{Use of a Low-Cost Soil Health Test Kit for Soil Evaluation and Farmer Education}

A low-cost soil health test kit was adapted from an existing test kit (USDA NRCS Soil Quality Institute 2001). The low-cost kit included tests for bulk density, soil infiltration, $\mathrm{pH}$ (EcoTestr $\mathrm{pH}$ 2, Oakton Instruments, Vernon Hills, IL), EC (EcoTestr EC high conductivity tester, Oakton Instruments), aggregate stability, and NPK levels (NPK soil test kit, Lamotte Company, Chestertown, MD). Each test kit had enough materials to test 50 fields at a cost of approximately 5 U.S. dollars per field. Researchers (two present per training) trained farmers $(n=32)$ to use the soil test kit. Pairs of farmers used the soil test kit to perform the various soil tests as they watched a trainer, and instructions were given verbally in Kiswahili. Each soil health test kit also included a pictorial guide with instructions and test interpretations in Kiswahili. One soil health test kit was left in each village for independent use by farmers.

Farmers completed a questionnaire, via an enumerator, regarding their attitudes and perceptions of their soils and soil testing immediately before soil test kit training. A subset of the trained farmers $(n=20)$ from each village was asked the same questions 1 month after soil test kit training to measure changes in attitudes and perceptions. Farmers' responses were given using a Likert-type scale with 1 meaning strongly disagree and 5 meaning strongly agree. Differences in farmers' responses before and after soil health test kit usage were determined using the Wilcoxon signed rank test in SPSS (IBM Corporation, Armonk, NY) with a significance level of $\alpha=0.05$.

One month following soil health test kit training, all respondents $(n=20)$ strongly agreed that the soil health test kit was useful, and

\begin{tabular}{|c|c|c|c|}
\hline $\begin{array}{r}\text { Soil health card dev } \\
\text { soil healt }\end{array}$ & ed for use by smallholder tom & $\begin{array}{l}\text { TABLE } 2 \\
\text { rmers in the Morogoro Region }\end{array}$ & $\begin{array}{l}\text { alitative descriptions of } \\
\text { it of the card. }\end{array}$ \\
\hline Indicator & Poor & Medium & Good \\
\hline Soil life & $\begin{array}{l}\text { No earthworms, termites, ants, other } \\
\text { beneficial organisms present in soil } \\
\text { (Test } 2 \text { shovels of soil) }\end{array}$ & $\begin{array}{l}\text { Few earthworms ( } 1 \text { to } 10) \text {, termites, } \\
\text { ants, other beneficial organisms } \\
\text { present in soil (Test } 2 \text { shovels of soil) }\end{array}$ & $\begin{array}{l}\text { Many earthworms }(10+) \text {, termites, ants, } \\
\text { other beneficial organisms present in } \\
\text { soil (Test } 2 \text { shovels of soil) }\end{array}$ \\
\hline Infiltration & $\begin{array}{l}\text { Water ponds for long periods following } \\
\text { rain/irrigation; soils remain } \\
\text { waterlogged }\end{array}$ & $\begin{array}{l}\text { Some ponding after rain/irrigation; } \\
\text { water eventually drains completely }\end{array}$ & $\begin{array}{l}\text { Water quickly moves into soil; no } \\
\text { ponding after rain/irrigation }\end{array}$ \\
\hline Water-holding capacity & $\begin{array}{l}\text { Plants wilt quickly following rain/ } \\
\text { irrigation; soil must be irrigated often }\end{array}$ & $\begin{array}{l}\text { Plants wilt normally following rains; } \\
\text { soil irrigated on a normal basis }\end{array}$ & $\begin{array}{l}\text { Plants do not wilt for long periods } \\
\text { following rain/irrigation; soil does not } \\
\text { need much irrigation }\end{array}$ \\
\hline Salts & $\begin{array}{l}\text { White crust forms on soil surface; } \\
\text { plants stunted/dead }\end{array}$ & Plants stunted; leaf edges "burnt" & $\begin{array}{l}\text { No white crust on soils; plants not } \\
\text { stunted; no leaf edge discoloration }\end{array}$ \\
\hline Root health & $\begin{array}{l}\text { Roots dead or dying; small root system; } \\
\text { majority of roots brown or black; } \\
\text { many galls on roots }\end{array}$ & $\begin{array}{l}\text { Good root system; some brown/black } \\
\text { areas on roots; few galls on roots }\end{array}$ & $\begin{array}{l}\text { Large, vigorous root system; no brown or } \\
\text { dead areas; no galls on roots }\end{array}$ \\
\hline Tilth/workability & $\begin{array}{l}\text { Soil difficult to break apart or plow; soil } \\
\text { powdery with no clumping; hard } \\
\text { surface forms on soil; large, } \\
\text { unbreakable clumps form in soil; } \\
\text { large rocks or stones }\end{array}$ & $\begin{array}{l}\text { Hard surface forms on soil but can be } \\
\text { broken apart; some breakable clumps } \\
\text { form in soil; soil somewhat difficult } \\
\text { to break apart; small rocks or gravel } \\
\text { present }\end{array}$ & $\begin{array}{l}\text { Soil easily plowed or broken apart by } \\
\text { shovel; no hard surface forms on soil; } \\
\text { no rocks or gravel }\end{array}$ \\
\hline Vegetation & $\begin{array}{l}\text { Soil bare unless planted; vegetation } \\
\text { stunted }\end{array}$ & $\begin{array}{l}\text { Some bare patches unless planted; } \\
\text { vegetation somewhat stunted }\end{array}$ & $\begin{array}{l}\text { Soil supports vigorous natural vegetation; } \\
\text { soil never bare; no plant stunting }\end{array}$ \\
\hline Smell & Decaying, sour smell & No smell & Fresh, earthy smell \\
\hline Fertility & $\begin{array}{l}\text { Soil has little organic matter; plants do } \\
\text { not respond to fertilization or lots of } \\
\text { fertilizer is required for a growth } \\
\text { response }\end{array}$ & $\begin{array}{l}\text { Soil has some organic matter; plants } \\
\text { respond somewhat to fertilization }\end{array}$ & $\begin{array}{l}\text { Soil has lots of organic matter; plants } \\
\text { respond well to fertilization or little } \\
\text { fertilization is required }\end{array}$ \\
\hline
\end{tabular}


all indicated that they would definitely use the soil health test kit in the future. Farmers also responded that the soil health test kit could be used to make soil management decisions (20\% agreed and $80 \%$ strongly agreed). All respondents also agreed (10\%) or strongly agreed (90\%) that the soil health card was useful, yet only 9 of 17 respondents (three nonresponses) actually reported using it. Nineteen of 20 farmers indicated that they would alter their soil management after using the soil health test kit and soil health card, and 16 of those farmers indicated they would apply some form of compost, manure, or mulch.

Significantly more farmers either agreed or strongly agreed that they were aware of soil testing services $(P=0.01$, Table 4$)$ and also had access to soil testing $(P=0.004)$ after using the soil health test kit than before the training. Significantly more farmers also agreed or strongly agreed that soil management recommendations were easier to understand following soil health test kit training $(P<0.0001$, Table 4). No significant differences were observed in farmers' responses to statements that their soils are an important resource, their management decisions affect their soils, they understand the different characteristics of their soils, they have help to make soil management decisions, they want to learn more about their soils or soil management, improved soil health is essential to the long-term success of their farm, access to soil testing can improve profitability, access to soil testing is important for all their crops, or they would like access to soil testing.

Use of the soil test kit changed how farmers look for information on their soils and who they would prefer to perform soil testing (options included self, another farmer, private business, extension agent, local government official, or university researcher). Prior to using the soil health test kit, $23 \%$ of respondents $(n=30$, farmers could select more than one answer) consulted other farmers, $50 \%$ consulted extension agents, $27 \%$ did not consult others, and 3\% consulted another source when looking for information about their soils. After using the soil health test kit, $30 \%$ of respondents $(n=20)$ said they consulted other farmers, $90 \%$ consulted an extension agent, $10 \%$ did not consult others, and $20 \%$ consulted another source, such as a university researcher, to gain information about their soils. Prior to using the soil test kit, $30 \%$ of farmers would prefer to test their soils themselves, $7 \%$ preferred a private business to carry out the testing, $57 \%$ preferred an extension agent to do it, and $97 \%$ preferred a university researcher to conduct the soil testing. Following the training, $90 \%$ of respondents $(n=19)$ would prefer to test their soils themselves, $16 \%$ preferred another farmer to perform testing, $84 \%$ preferred an extension agent, and $84 \%$ preferred a university researcher to perform the testing. Prior to using the soil

\section{TABLE 3}

Soil health card developed for use by smallholder tomato farmers in the Morogoro Region of Tanzania. The reverse side of the card contains descriptions of soil management practices that improve or worsen the status of each indicator.

Indicator Soil management practices to improve indicator

Soil life

Compaction

Infiltration

Water-holding capacity

Crop vigor

Salts

Root health

Tilth/workability

Vegetation

Aggregation

Erosion

Smell

Fertility
Add organic matter

Do not work in fields when wet

Reduce the people, animals, and machinery traveling through fields

Add organic matter

Avoid compacting soils

Grow a deep-rooted crop such as sunflower

Keep soil covered to avoid crust formation

Add organic matter

Add organic matter

Fertilize crop

Prevent erosion of topsoil

Do not excessively fertilize

Do not use a salty water source for irrigation

Flush soils with excess irrigation water

Rotate with a different crop for several seasons to reduce pathogen populations

Add organic matter

Add organic matter

Allow plants to cover soil between crops

Add organic matter

Use a mulch when cropping

Do not plant on steep areas if possible

If necessary, disturb soil as little as possible

Till along contours of slopes

Improve soil drainage

Add organic matter

Add organic matter

Rotate with a legume crop

Fertilize with manure or inorganic fertilizers
Things that make indicator worse

Overapplication of inorganic fertilizers

Working in fields when wet

Driving over fields

Using heavy equipment in fields

Practices that compact soils

Burning crop residues on fields

Low soil organic matter

Excessive tillage

Soil erosion

Plant diseases

Lack of nutrients

Soil erosion

Excessive fertilization

Irrigation with a saline water source

Growing the same crop repeatedly

Rotating with crops that are closely related to each other

(such as tomato and African eggplant)

Low soil organic matter

Soil compaction

Low soil organic matter

Excessive tillage

Planting on slopes

Working soils excessively on slopes

Irrigating on slopes

Soil compaction

Poor soil drainage

Not using proper fertilization

No legumes in rotations 
TABLE 4

Tomato farmer perceptions of soil and soil management before and after use of a low-cost soil health test kit in the Morogoro

Region of Tanzania. Farmers responded using a Likert-type scale, and the percent of respondents that either agreed or strongly agreed is shown. Pre- and postsurvey responses were compared using the Wilcoxon signed-ranks test.

\section{Statement}

My soils are an important resource

My management decisions affect my soils

I have help to make soil management decisions

I understand different characteristics of my soils

I want to learn more about my soils

I want to learn more about soil management

Improved soil health is essential for long-term success of

my farm

Access to soil testing can improve my profitability

Access to soil testing is important for all my crops

I would like access to soil testing

I am aware of soil testing services

I have access to soil testing services

Soil management recommendations are easy to

understand

Wilcoxon signed-ranks Presurvey $(n=14)^{y}$

Postsurvey $(n=14)$ $Z$ value $(P \text { value })^{Z}$

${ }^{y}$ Percent of respondents who either agreed or strongly agreed. In parentheses, median value of given responses on a Likert-type scale: 1 = strongly disagree; $2=$ disagree; $3=$ neutral; $4=$ agree $;$ and $5=$ strongly agree.

${ }^{\mathrm{z}} P$ value given in parentheses is for two-tailed exact calculation.

test kit, farmers $(n=28)$ trusted themselves $(4 \%)$, an extension agent $(7 \%)$, or a university researcher $(89 \%)$ most to conduct the soil test. After using the soil test kit, $26 \%$ of respondents $(n=19)$ trusted themselves the most, $5 \%$ trusted another farmer, and $69 \%$ trusted a university researcher.

The majority of farmers (18 of 20) interviewed would be willing to pay someone to test their soils using the soil health test kit, and on average, farmers were willing to pay up to 9,200 Tanzanian shillings per field (4 to 5 U.S. dollars). When asked what parts of the soil test kit were most helpful, $35 \%$ of respondents $(n=20)$ stated nutrient testing or soil infiltration rates, followed by EC $(20 \%), \mathrm{pH}$ $(15 \%)$, and aggregate stability $(10 \%)$. Only half $(n=10)$ of the farmers surveyed provided responses to the question of which tests in the kit were least useful to them. Of those respondents, $30 \%$ considered bulk density and the $\mathrm{pH} / \mathrm{EC}$ tests least helpful, $20 \%$ felt temperature or aggregate stability were least helpful, and one respondent felt infiltration was not helpful.

Farmers were also interviewed via enumerator 1 year following initial training to estimate long-term adoption of the soil health test kit. The farmers selected for interviews were a subset of the 32 farmers across the three villages who had been trained on the use of the soil health test kit. Farmers were asked about their use of the soil health test kit and soil health card and their opinions on these tools. All of the 24 farmers interviewed 1 year after training had used the soil health test kit independently following completion of the original training. Farmers worked together in groups to test multiple fields, with farmers stating that they were present for testing an average of 15 fields. Fields were tested in groups that consisted of, on average, nine farmers. The majority of farmers (17 of 24) used all tests in the soil health kit. Bulk density (4 of 24 did not use) and aggregate stability ( 5 of 24 ) were the tests most often not used. All respondents either agreed or strongly agreed that the soil health test kit helped them to understand their soils and helped them to identify soil management strategies. Nearly all respondents also used the soil health card (21 of 24 , an increase from initial surveys 1 month after using the kit), and these respondents all agreed or strongly agreed that the soil health card also helped them to understand their soils and helped them to identify soil management strategies. In open-ended discussions, farmers often stated that the soil health test kit and soil health card were most helpful when used together. The farmers also stated that they felt the soil health test kit would be unsustainable unless a reliable source could be found to replenish consumables, such as the NPK test. Farmers expressed a strong desire for ongoing support from extension agents and university researchers.

\section{Expanding Farmers' Capacities to Monitor and Manage Soil Health}

The ability to monitor soil health is essential to farm sustainability. However, resources for evaluating soil health, such as access to soil testing and extension agents, are often unavailable to smallholder farmers in developing countries. A better understanding of soil health on tomato farms in the Morogoro Region of Tanzania and how farmers evaluated soil health using local soil knowledge, along with tools to enable farmers to monitor soil health independently, were developed in this project.

Baseline soil fertility characteristics in tomato fields in the Morogoro Region were identified in this study. The soils surveyed in this project should be suitable for continued tomato production in the region when combined with good agricultural practices, improved germplasm, and proper fertilizer use (Zingore et al. 2014). It is currently difficult to find appropriate soil management recommendations for horticultural crops in targeted regions, let alone countries, in sub-Saharan Africa. Many sweeping soil management recommendations are designed for the production of staple crops for the entirety of sub-Saharan Africa, and there is a great need to strengthen soil management recommendations for smallholder farmers with an emphasis on production of high-value horticultural crops (Maro et al. 2013) in specific countries and regions. More studies to identify baseline soil characteristics for horticultural crop production should be performed in sub-Saharan Africa to improve soil management recommendations for the sustainable production of these high-value 
crops. The results of this study and similar studies could be used to develop these targeted soil management recommendations.

Farmers in the Morogoro Region currently use local soil knowledge to evaluate the health of their soils. We used a participatory approach (Chambers 1994) to elicit local soil knowledge. Local soil knowledge is essential in farmer selection of fields, and previous studies have indicated that fields that farmers identify as being more fertile for crop production do, in fact, have better soil test values than "nonfertile" fields (Mairura et al. 2007; Mowo et al. 2006). Therefore, it is valuable for researchers to understand and incorporate local soil knowledge to develop a better understanding of regional soil health. Morogoro farmers described their soils most often in terms of soil texture and tilth, soil water relations, and soil color, which is consistent with other systems of local soil knowledge (Barrera-Bassols and Zinck 2003; Ettema 1994) and with other studies in Eastern Africa (Mairura et al. 2007; Mowo et al. 2006; Murage et al. 2000). The majority of farmers interviewed identified soils problematic for tomato production. These farmers also identified the soil property thought to constrain crop productivity, yet these self-diagnoses may be incorrect, and farmers could benefit from formalized methods to evaluate soils. The soil health card was developed as a means to formalize assessment of local soil health indicators based on local soil knowledge (Romig et al. 1995; USDA NRCS Soil Quality Institute 1999), so that farmers could qualitatively evaluate the health of their soils on a consistent basis. This card was well received by farmers, with $88 \%$ of farmers $(n=24)$ continuing to use this card after 1 year. Soil health cards have practical applications beyond use by individual farmers; similar cards were used to facilitate land use planning in Kilimanjaro, Tanzania (Sangeda et al. 2014).

Farmers must also be able to evaluate technical indicators of soil health to improve crop productivity. Farmers were taught to use a low-cost soil test kit, which served two purposes: to educate farmers on various soil properties and to empower them to assess soils on their own. Use of the soil test kit affected farmers' perceptions of soil testing. Following use of the test kit, farmers expressed increased awareness of soil testing, increased access to soil testing, and a better understanding of soil management recommendations. Farmers strongly valued their soils before using the soil test kit, as indicated in their pre-use responses, so use of the soil test kit did not significantly affect their perceptions of the value of their soils. Use of the soil test kit also altered farmers' perceptions of those most preferred and trusted to perform soil testing, with preferences shifting to farmer-led testing following training.

Several aspects of the soil health test kit must be considered and altered to improve kit usage and adoption in the future. Appropriate program evaluation methods, such as outcome mapping, must be implemented during deployment of soil health test kits to ensure stakeholder participation (Testen et al. 2016b) and achievement of program objectives. Consumables used in the kit, such as the NPK test, should be procurable within country or tests developed that use locally available materials. Farmers are able to assess soils on their own using the soil health test kit, but extension agents and university researchers would need to provide ongoing recommendations and support for farmers using the kit (Wander and Drinkwater 2000). Additional tests, such as bioassays to assess for soilborne diseases (Gugino et al. 2009; Testen et al. in press) or rapid tests for soil carbon (Weil et al. 2003), would be valuable additions to future iterations of low-cost soil health test kits. The soil health test kit has potential for commercialization for low-cost soil testing. The suite of tests contained in the soil health test kit costs approximately 5 U.S. dollars per field, making the kit a cost-effective means of farmer education. The majority (90\%) of Morogoro farmers interviewed indicated that they would be willing to pay 4 to 5 U.S. dollars for use of the soil health test kit, so commercialization may be a means to support continued purchase of kit consumables.

Adoption of a low-cost soil health test kit that is simple and reliable to use could greatly improve soil health practices by smallholder farmers. Use of a soil test kit empowers farmers to identify potential soil problems and can improve farmers' communication of these problems to external organizations, such as nongovernmental organizations or local universities (Wander and Drinkwater 2000). Several approaches, such as the SoilDoc (American Society of Agronomy/ Crop Science Society of America 2013), have been used to improve extension agents' ability to evaluate soils quantitatively for farmers, yet extension infrastructure is often poorly developed across the developing world (Daniel 2013; UN FAO 2009). Although the soil health test kit may be better used by extension agents, farmer use of the soil health test kit changed farmers' perceptions toward soil testing access and soil management. Improving farmers' understanding of soil properties can increase their prioritization of soil stewardship (Wander and Drinkwater 2000), which is the first step toward improving and sustaining soil health. The hands-on, participatory nature of the soil test kit and soil health card also brings abstract soil concepts into focus for farmers, leading to a more concrete understanding (Trope and Liberman 2010) of these concepts in their minds, in turn likely affecting their perceptions of soil management.

Efforts to address the soil constraints faced by smallholder farmers in Tanzania are ongoing, and researchers must combine tried-andtrue methods with innovative approaches to develop appropriate solutions. A key component of successful soil health programs is the inclusion of local soil knowledge. This local soil knowledge paired with innovative soil health assessment tools, such as soil health cards or low-cost soil health test kits, provides farmers with something both familiar and new that they can use to identify and address soil health constraints in their fields. These tools, integrated into a broader program that includes continued education and sustained extension and research support, can help smallholder farmers to identify and address soil health issues in their own fields, potentially improving soil and plant health and crop productivity.

\section{Acknowledgments}

This research was supported by the United States Agency for International Development Feed the Future Initiative through a collaborative research grant through the Innovative Agriculture Research Initiative (iAGRI, Award Number 621-A-00-11-00009-00), a United States Borlaug Fellows in Global Food Security graduate student research grant to A. L. Testen (award number 206766), and by state and federal funds appropriated to the Ohio Agricultural Research and Development Center, The Ohio State University. This research was reviewed and approved by The Ohio State University Institutional Review Board under protocol numbers 2013E0502 and 2014E0219. We thank our farmer collaborators for their participation and feedback in this research.

\section{Literature Cited}

American Society of Agronomy/Crop Science Society of America. 2013. New soil testing kit for third world countries. ScienceDaily. https://www.sciencedaily. com/releases/2013/10/131016145359.htm, accessed November 15, 2015.

Barrera-Bassols, N., and Zinck, J. A. 2003. Ethnopedology: A worldwide view on the soil knowledge of local people. Geoderma 111:171-195.

Barrios, E., Bekunda, M., Delve, R., Esilaba, A., and Mowo, J. 2000. Methodologies for Decision Making in Natural Resource Management: Identifying and Classifying Local Indicators of Soil Quality, Eastern Africa Version. International Center of Tropical Agriculture, Cali, Colombia.

Bray, R. H., and Kurtz, L. T. 1945. Determination of total, organic, and available forms of phosphorus in soils. Soil Sci. 59:39-46.

Chambers, R. 1994. The origins and practice of participatory rural appraisal. World Dev. 22:953-969.

Culman, S. W., Snapp, S. S., Freeman, M. A., Schipanski, M. E., Beniston, J., Lal, R., Drinkwater, L. E., Franzluebbers, A. J., Glover, J. D., Grandy, A. S., Lee, J., Six, J., Maul, J. E., Mirksy, S. B., Spargo, J. T., and Wander, M. M. 
2012. Permanganate oxidizable carbon reflects a processed soil fraction that is sensitive to management. Soil Sci. Soc. Am. J. 76:494-504.

Daniel, E. 2013. Assessment of agricultural extension services in Tanzania: A case study of Kyela, Songea Rural, and Morogoro Rural Districts. Wageningen University, Wageningen, Netherlands.

Day, P. R. 1965. Particle fractionation and particle-size analysis. Pages 545-567 in: Methods of Soil Analysis. Part 1. Physical and Mineralogical Properties, Including Statistics of Measurement and Sampling. C.A. Black, ed. American Society of Agronomy, Madison, WI. https://dl.sciencesocieties.org/publications/ books/abstracts/agronomymonogra/methodsofsoilana/545 ?access $=0 \&$ view=pdf, accessed November 25, 2015.

Ditzler, C. A., and Tugel, A. J. 2002. Soil quality field tools: Experiences of USDA-NRCS Soil Quality Institute. Agron. J. 94:33-37.

Doran, J. W., Sarrantonio, M., and Liebig, M. A. 1996. Soil health and sustainability. Adv. Agron. 56:1-54.

Ellis-Jones, J., and Tengberg, A. 2000. The impact of indigenous soil and water conservation practices on soil productivity: Examples from Kenya, Tanzania, and Uganda. Land Degrad. Dev. 11:19-36.

Erkossa, T., Stahr, K., and Gaiser, T. 2004. Participatory soil quality assessment: The case of smallholder farmers in Ethiopian highlands. Aust. J. Soil Res. 42: 793-797.

Esipisu, I. 2015. A mobile soil testing facility now available in Kenya. PAMACC News. http://pamaccafrica.blogspot.com/2015/10/a-mobile-soil-testing-facilitynow.html, accessed October 28, 2015.

Ettema, C. H. 1994. Indigenous Soil Classifications: What Are Their Structure and Function, and How do They Compare to Scientific Soil Classifications? University of Georgia, Athens, GA.

Gugino, B. K., Idowu, O. J., Shindelbeck, R. R., van Es, H. M., Wolfe, D. W., Moebius-Clune, B. N., Thies, J. E., and Abawi, G. S. 2009. Cornell Soil Health Assessment Training Manual, Edition 2.0. Cornell University, Geneva, NY.

Heuvelink, E. ed. 2005. Tomatoes. CABI Publishing, Wallingford, UK. doi.org/ 10.1079/9780851993966.0000

Liebig, M. A., Doran, J. W., and Gardner, J. C. 1996. Evaluation of a field test kit for measuring selected soil quality indicators. Agron. J. 88:683-686.

Maerere, A. P., Sibuga, K. P., Bulali, J. E. M., Mwatawala, M. W., Kovach, J., Kyamanywa, S., Mtui, H. D., and Erbaugh, M. 2010. Deriving appropriate pest management technologies for smallholder tomato (Solanum lycopersicum Mill.) growers: A case study of Morogoro, Tanzania. J. Anim. Plant Sci. 6:663-676.

Mairura, F. S., Mugendi, D. N., Mwanje, J. I., Ramisch, J. J., Mbugua, P. K., and Chianu, J. N. 2007. Integrating scientific and farmers' evaluation of soil quality indicators in Central Kenya. Geoderma 139:134-143.

Maro, G. P., Mrema, J. P., Msanya, B. M., and Teri, J. M. 2013. Farmers' perception of soil fertility problems and their attitudes towards integrated soil fertility management for coffee in Nothern Tanzania. J. Soil Sci. Environ. Manag. 4:93-99.

Minja, R. R., Ambrose, J., Ndee, A., Swai, I. S., and Ojiewo, C. O. 2011. Promising improved tomato varieties for Eastern Tanzania. Afr. J. Hortic. Sci. 4:24-30.

Mowo, J. G., Janssen, B. H., Oenema, O., German, L. A., Mrema, J. P., and Shemdoe, R. S. 2006. Soil fertility evaluation and management by smallholder farmer communities in northern Tanzania. Agric. Ecosyst. Environ. 116:47-59.

Msanya, B. M., Kaaya, A. K., Araki, S., Otsuka, H., and Nyadzi, G. I. 2003. Pedological characteristics, general fertility and classification of some benchmark soils of Morogoro District, Tanzania. Afr. J. Sci. Technol. 4:101-111.

Murage, E. W., Karanja, N. K., Smithson, P. C., and Woomer, P. L. 2000. Diagnostic indicators of soil quality in productive and non-productive smallholders' fields of Kenya's Central Highlands. Agric. Ecosyst. Environ. 79:1-8.

Nakkazi , E. 2014. Uganda gets mobile lab to spur farmers' soil know-how. Sci Dev Net. https://www.scidev.net/index.cfm?originalUrl=sub-saharan-africa/ agriculture/news/uganda-gets-mobile-lab-to-spur-farmers-soil-know-how.html, accessed October 28, 2015.
Nelson, D. W., and Sommers, L. E. 1996. Total carbon, organic carbon, and organic matter. Pages 961-1010 in: Methods of Soil Analysis, Part 3-Chemical Methods. Soil Science Society of America Book Series 5. D. L. Sparks, ed. American Society of Agronomy, Madison, WI.

Niemeijer, D., and Mazzucato, V. 2003. Moving beyond indigenous soil taxonomies: Local theories of soils for sustainable development. Geoderma 111: 403-424.

Oudwater, N., and Martin, A. 2003. Methods and issues in exploring local knowledge of soils. Geoderma 111:387-401.

Paavola, J. 2008. Livelihoods, vulnerability and adaptation to climate change in Morogoro, Tanzania. Environ. Sci. Policy 11:642-654.

Ponte, S. 1998. Fast crops, fast cash: Market liberalization and rural livelihoods in Songea and Morogoro Districts, Tanzania. Can. J. Afr. Stud., Rev. Can. Études Afr. 32:316-348.

Romig, D. E., Garlynd, M. J., Harris, R. F., and McSweeney, K. 1995. How farmers assess soil health and quality. J. Soil Water Conserv. 50:229-236.

Sangeda, A. Z., Kahimba, F. C., Kashaga, R. A. L., Semu, E., Mahonge, C. P., and Mkada, F. X. 2014. Testing of decision making tools for village land use planning and natural resources management in Kilimanjaro Region. Open J. Soil Sci. 4:446-458

Sumner, M. E., and Miller, W. P. 1996. Cation exchange capacity and exchange coefficients. Pages 1201-1229 in: Methods of Soil Analysis Part 3-Chemical Methods. D. L. Sparks, ed. American Society of Agronomy, Madison, WI. https://dl.sciencesocieties.org/publications/books/abstracts/sssabookseries/ methodsofsoilan3/1201/preview, accessed November 26, 2015.

Testen, A. L., Mamiro, D. P., Mtui, H. D., Nahson, J., Mbega, E. R., Francis, D. M., and Miller, S. A. 2016a. Introduction and evaluation of tomato germplasm by participatory mother and baby trials in the Morogoro Region of Tanzania. HortScience 51:1467-1474

Testen, A. L., Mamiro, D. P., Nahson, J., Mtui, H. D., and Miller, S. A. 2016 b. Evaluation of plant health programs using outcome mapping. Plant Health Prog. 17:254-260.

Testen, A. L., Mamiro, D. P., Nahson, J., Mtui, H. D., Paul, P. A., and Miller, S. A. In press. Integrating ethnophytopathological knowledge and field surveys to improve tomato disease management in Tanzania. Can. J. Plant Pathol. doi/org/ 10.1080/07060661.2017.1414881

Trope, Y., and Liberman, N. 2010. Construal-level theory of psychological distance. Psychol. Rev. 117:440-463.

UN FAO. 2009. Family Farming Knowledge Platform, Tanzania, 2009. UN FAO, Rome.

USDA NRCS Soil Quality Institute. 1999. Soil quality card design guide. U.S. Department of Agriculture, Natural Resources Conservation Service, Washington, D.C

USDA NRCS Soil Quality Institute. 2001. Soil Quality Test Kit Guide. U.S. Department of Agriculture, Natural Resources Conservation Service, Washington, D.C.

Vanlauwe, B., and Giller, K. E. 2006. Popular myths around soil fertility management in sub-Saharan Africa. Agric. Ecosyst. Environ. 116:34-46.

Wander, M. W., and Drinkwater, L. E. 2000. Fostering soil stewardship through soil quality assessment. Appl. Soil Ecol. 15:61-73.

Weil, R. R., Islam, K. R., Stine, M. A., Gruver, J. B., and Samson-Liebig, S. E. 2003. Estimating active carbon for soil quality assessment: A simplified method for laboratory and field use. Am. J. Altern. Agric. 18:3-17.

Wilke, B.-M. 2005. Determination of chemical and physical soil properties. Pages 47-95 in: Monitoring and Assessing Soil Bioremediation. R. Margesin and F. Schinner, eds. Soil Biology, Vol. 5. Springer, Berlin.

Zingore, S., Njoroge, S., Chikowo, R., Kihara, J., Nziguheba, G., and Nyamangara, J. 2014. 4R Plant nutrient management in African agriculture: An extension handbook for fertilizer management in smallholder farming systems. International Plant Nutrition Institute sub-Saharan Africa, Nairobi, Kenya. 